\title{
Interfering amino-terminal peptides and functional implications for heteromeric gap junction formation
}

\author{
Eric C. Beyer ${ }^{1}$, Xianming Lin ${ }^{2 \dagger}$ and Richard D. Veenstra ${ }^{2} *$ \\ ' Department of Pediatrics, University of Chicago, Chicago, IL, USA \\ ${ }^{2}$ Department of Pharmacology, State University of New York Upstate Medical University, Syracuse, NY, USA
}

\section{Edited by:}

Aida Salameh, Heart Centre

University of Leipzig, Germany

Reviewed by:

Motohiro Nishida, Kyushu University,

Japan

Stefan Dhein, Universitätsklinik

Leipzig Herzzentrum Leipzig GmbH,

Germany

\section{*Correspondence:}

Richard D. Veenstra, Department of Pharmacology, State University of New York Upstate Medical University, 750 East Adams Street, Syracuse, NY 13210, USA.

e-mail:veenstrr@upstate.edu

${ }^{\dagger}$ Present address:

Xianming Lin, Leon H. Charney Division of Cardiology, New York University School of Medicine, New York, NY 10016, USA.
Connexin43 (Cx43) is widely expressed in many different tissues of the human body. In cells of some organs, $\mathrm{Cx} 43$ is co-expressed with other connexins $(\mathrm{Cx})$, including $\mathrm{C} \times 46$ and $\mathrm{C} \times 50$ in lens, $\mathrm{C} \times 40$ in atrium, Purkinje fibers, and the blood vessel wall, Cx45 in heart, and Cx37 in the ovary. Interactions with the co-expressed connexins may have profound functional implications. The abilities of $\mathrm{C} \times 37, \mathrm{C} \times 45, \mathrm{C} \times 46$, and $\mathrm{C} \times 50$ to function in heteromeric gap junction combinations with $\mathrm{C} \times 43$ are well documented. Different studies disagree regarding the ability of $\mathrm{C} \times 43$ and $\mathrm{C} \times 40$ to produce functional heteromeric gap junctions with each other. We review previous studies regarding the heteromeric interactions of $\mathrm{Cx} 43$. The possibility of negative functional interactions between the cytoplasmic pore-forming amino-terminal (NT) domains of these connexins was assessed using pentameric connexin sequence-specific NT domain [interfering NT (iNT)] peptides applied to cells expressing homomeric $\mathrm{C} \times 40, \mathrm{C} \times 37, \mathrm{C} \times 45, \mathrm{C} \times 46$, and $\mathrm{C} \times 50$ gap junctions. A $\mathrm{C} \times 43$ iNT peptide corresponding to amino acids 9-13 (Ac-KLLDK-NH $\left.{ }_{2}\right)$ specifically inhibited the electrical coupling of $\mathrm{C} \times 40$ gap junctions in a transjunctional voltage $\left(V_{\mathrm{j}}\right)$-dependent manner without affecting the function of homologous $\mathrm{C} \times 37, \mathrm{C} \times 46, \mathrm{C} \times 50$, and $\mathrm{C} \times 45$ gap junctions. $\mathrm{A} \times \mathbf{C} 40$ iNT (Ac-EFLEE-OH) peptide counteracted the $V_{j}$-dependent block of $\mathrm{C} \times 40$ gap junctions, whereas a similarly charged Cx50 iNT (Ac-EEVNE-OH) peptide did not, suggesting that these NT domain interactions are not solely based on electrostatics. These data are consistent with functional $\mathrm{C} \times 43$ heteromeric gap junction formation with $\mathrm{C} \times 37, \mathrm{C} \times 45, \mathrm{C} \times 46$, and $\mathrm{C} \times 50$ and suggest that $\mathrm{C} \times 40$ uniquely experiences functional suppressive interactions with a $\mathrm{C} \times 43 \mathrm{NT}$ domain sequence. These findings present unique functional implications about the heteromeric interactions between $\mathrm{C} \times 43$ and $\mathrm{C} \times 40$ that may influence cardiac conduction in atrial myocardium and the specialized conduction system.

\section{Keywords: connexin43, connexin40, gap junction, heteromeric channel, spermine}

\section{INTRODUCTION}

Gap junctions facilitate the metabolic, biochemical, and electrical integration of component cells into functional tissues, because they contain intercellular channels that link them while excluding access to the extracellular milieu. The task of coupling the cells of the various tissues in the body is accomplished by 20 different connexin $(\mathrm{Cx})$ proteins. Although the requirement for so many different connexins is not well understood and there are some functional redundancies, there are significant differences in functional properties among the channels formed of different connexins (including conductance, permeability, and gating).

Essentially all mammalian tissues (and most of the cells within them) contain more than one connexin. The expression of multiple connexins provides the opportunity for interactions with each other to form heteromeric and heterotypic channels. The properties of the resulting hetero-oligomeric channels can have a diversity of functional properties determined by their different subunits, the interactions of those subunits, and the stoichiometries of the interactions.

In previous studies, we have particularly focused on $\mathrm{Cx} 43$ and its interactions with other co-expressed connexins. $\mathrm{Cx} 43$ is one of the most widely expressed connexins. It has been found in some cells in most organs of the body, and it has been implicated in significant functions in smooth muscle, myocardium, astrocytes, lens epithelium, endothelium, etc. Many of these cells also contain other connexins. Cx43 is most commonly found with the other connexins that have the most similar sequences including Cx37, $\mathrm{Cx} 40, \mathrm{Cx} 46$, and Cx50 (that are members of the $\alpha$ sub-family of connexins encoded by the gap junction alpha (GJA) group of genes; Kumar and Gilula, 1992; Beyer and Berthoud, 2009).

The functional interactions of $\mathrm{Cx} 43$ with other connexins have been extensively studied by expression of the connexins in Xenopus oocytes or in transfected communication-deficient cells. Such studies have consistently shown that $\mathrm{Cx} 43$ will form functional heteromeric and/or heterotypic gap junction channels with three $\alpha$-connexins, $\mathrm{Cx} 37, \mathrm{Cx} 46, \mathrm{Cx} 50$, and with $\mathrm{Cx} 45$ (now classified as a $\gamma$-connexin), but not with the $\beta$ sub-family connexins, $\mathrm{Cx} 26$ and Cx32 (White et al., 1994, 1995; Elfgang et al., 1995; Brink et al., 1997; Berthoud et al., 2001; Martinez et al., 2002; Gemel et al., 2004). These functional interactions between $\mathrm{Cx} 43$ and other connexins may have significant functional consequences, like generation of a large variety of different channel sizes (Brink et al., 
1997) or alteration of permeability, gating, and phosphorylationdependent regulation (Elenes et al., 2001; Martinez et al., 2002). Some of these studies are supported by biochemical data showing the co-isolation of the co-expressed connexin with Cx43 in hexamers.

The ability of $\mathrm{Cx} 43$ and $\mathrm{Cx} 40$ to form functional interactions within mixed channels is controversial. Initial reports of studies conducted using Xenopus oocytes or HeLa cell transfectants concluded that this pair of connexins could not make functional heterotypic channels (Bruzzone et al., 1993; Elfgang et al., 1995; White et al., 1995; Haubrich et al., 1996). However, these observations were contradicted by subsequent reports of functional $\mathrm{Cx} 43-\mathrm{Cx} 40$ heterotypic interactions in pairs of neuro 2a (N2a) cells (Valiunas et al., 2000) and rat insulinoma (RIN) cells (Cottrell and Burt, 2001). When Veenstra and colleagues paired $\mathrm{Cx} 43$ with a $\mathrm{Cx} 40$ mutant containing substitutions of two charged residues (Musa et al., 2004), they observed symmetrically convergent alterations of voltage-dependent gating, arguing for Cx43-Cx40 heterotypic interactions (Lin et al., 2011; and unpublished results). But, in contrast, a study of connexins tagged with fluorescent proteins at their C-termini concluded that Cx40 and $\mathrm{Cx} 43$ only appeared to make heterotypic gap junctions when $\mathrm{Cx} 45$ (which could interact with either connexin) was co-expressed (Rackauskas et al., 2006).

However, the issue of heterotypic interactions between these connexins should only have importance in the rare case of a cell producing only $\mathrm{Cx} 40$ contacting another expressing only $\mathrm{Cx} 43$. In contrast, the possible heteromeric interaction of these connexins may occur frequently in cells (such as atrial myocytes and some endothelial cells) that co-express both connexins.

Several studies have supported the abilities of $\mathrm{Cx} 40$ and $\mathrm{Cx} 43$ to form functional heteromers. Mixed heteromers of these two connexins were identified by affinity purification or coimmunoprecipitation studies performed using co-expressing cells (He et al., 1999; Valiunas et al., 2001). In transfected N2A cells, Valiunas et al. (2001) observed a rather low total conductance in pairs of cells expressing both $\mathrm{Cx} 40$ and $\mathrm{Cx} 43$, with only a rather small variation in single channel conductances and alterations of voltage-dependent gating; they suggested that $\mathrm{Cx} 40$ Cx43 heteromers might form inefficiently and many might be non-functional. Burt and colleagues have extensively studied the consequences of $\mathrm{Cx} 40$ and $\mathrm{Cx} 43$ co-expression in A7r5 and RIN cells, including pairs of cells with different relative expression ratios (Cottrell and Burt, 2001; Cottrell et al., 2002; Burt and Steele, 2003; Heyman et al., 2009). Their data suggest that these two connexins readily form heteromeric channels and that the composition of these channels influences many properties including gating, conductance, permeability, charge selectivity, and response to platelet-derived growth factor (PDGF).

The domains within the connexin protein that influence oligomerization between subunits to form a hexamer and between different connexins to form a heteromeric hexamer have not been clearly defined. However, various biochemical and mutagenesis studies have implicated residues within the amino-terminal (NT) and within the first and third transmembrane domains (Lagree et al., 2003; Maza et al., 2005; Martinez et al., 2011). The NT has also been implicated in contributing to various channel properties including voltage-dependent gating, unitary conductance, and perm-selectivity (Oh et al., 2000, 2004; Veenstra, 2003; Musa et al., 2004; Dong et al., 2006; Gemel et al., 2006; Tong and Ebihara, 2006; Veenstra and Lin, 2006).

Some gap junction channels are very sensitive to block by polyamines like spermine and spermidine (Musa etal., 2001; Musa and Veenstra, 2003). However, this block is selective among connexins with $\mathrm{Cx} 40$ being very sensitive and $\mathrm{Cx} 43$ insensitive (Musa and Veenstra, 2003). Mutagenesis studies suggest that this connexin-specific difference is imparted by N-terminal amino acids (Musa et al., 2004; Gemel et al., 2006; Lin et al., 2006). Specifically, replacement of two negatively charged residues (E9 and E13) in Cx40 with the corresponding positively charged residues (K9 and K13) of Cx43 abolished spermine block (Musa et al., 2004). This also suggested that the block of Cx40 (but not Cx43) channels by spermine might involve interaction with these NT residues.

Polyamines (including putrescine, spermidine, and spermine) are ubiquitous polybasic molecules that interact with a wide variety of cellular molecules including nucleic acids, nucleotide triphosphates, phospholipids, and acidic proteins and influence gene transcription and translation, signaling pathways, enzyme activities, and ion channel function essential to eukaryotic cell growth and mammalian development (Igarashi and Kashiwagi, 2000; Pegg, 2009). Thus connexin channels are only one of many intracellular targets that may be modulated by cytoplasmic polyamines.

The NT domain of the connexins consists of their first 22-23 amino acids. Some of the amino acids within the NT are highly conserved, while others are variable and contribute to different properties. (The NT domains of several connexins are shown in alignment in Figure 1.) The structure of the NT domain was initially investigated by studying synthetic peptides using circular dichroism and nuclear magnetic resonance (Purnick et al., 2000; Arita et al., 2006; Kalmatsky et al., 2009; Kyle et al., 2009). Each of these studies showed that much of the beginning of the NT is $\alpha$-helical, although they differ in the exact helical region; Purnick et al. (2000) concluded that the $\alpha$-helix in Cx26 extended from position 1 to 10 while Kyle et al. (2009) suggested that it extended between amino acids 5 and 15 in Cx37. When Maeda et al. (2009) determined the structure of a Cx26 channel at $3.5 \AA$ resolution, they observed that the NT regions of the six subunits lined the pore entrance and formed a "funnel," which restricts the diameter at the entrance of the pore. The beginning of the NT is located deep within the pore. The NT helix extends beyond the cytoplasmic side of the membrane and then forms a loop (including the highly conserved amino acids corresponding to the serine and threonine at positions 18 and 19 in Figure 1) that bends back to the membrane where TM1 begins. Although all of the connexins may have homologies, their NT domains do not necessarily assume identical configurations. The $\beta$-connexins were proposed to have a "glycine hinge" including and following amino acids 12 and 13 (Purnick et al., 2000; that correspond to amino acids 13 and 14 in the $\alpha$-connexins); however, insertion of the SG/GG ( $\beta$-connexin) motif into $\mathrm{Cx} 40$ or $\mathrm{Cx} 43 \mathrm{NT}$ abolishes $V_{\mathrm{j}}$-gating, suggesting a structural/functional disparity between the sub-families (Gemel et al., 2006). 

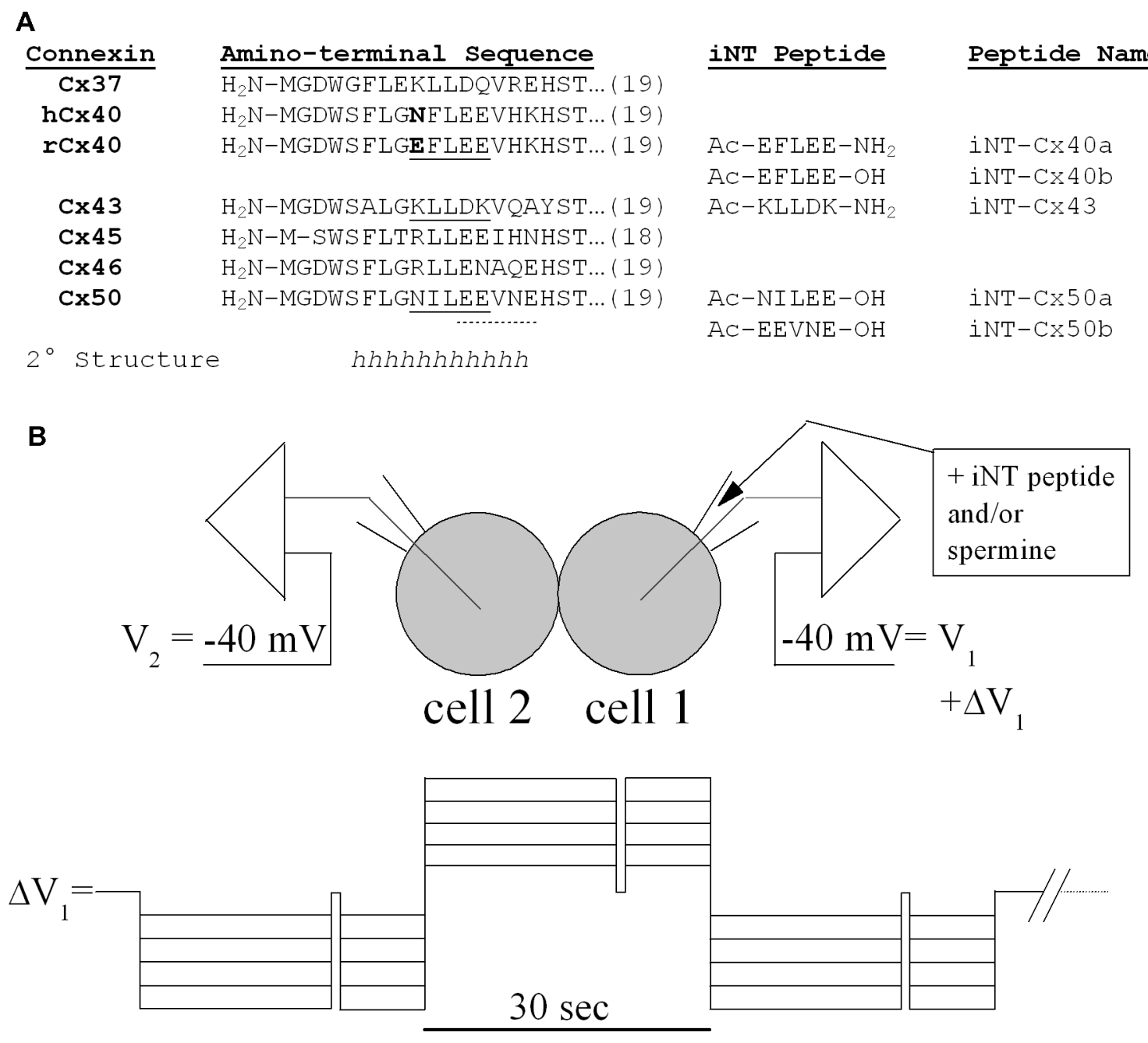

FIGURE 1 | (A) The amino acid sequences of the first 18 or 19 amino acids are shown for six different connexins and aligned with each other. The sequences in this NT region are identical for the homologous connexins in rodents or humans except for $\mathrm{C} \times 40$ (which differs at position 9 as shown in bold). A substantial part of the NT domain is likely to form $\alpha$-helices (h) based on consensus secondary structure predictions Neenstra and Lin, 2006), nuclear magnetic resonance studies (Kyle et al., 2009), and homology modeling to the X-ray structure of Cx26 (Maeda etal., 2009).
In the current study, we examined the possibility of differential regulation of channels made of different connexins through interactions of their NT domains. Based on their inhibition by spermine, we hypothesized that $\mathrm{Cx} 40$ channels might be blocked by short peptides that contained similarly spaced positively charged residues, like the $\mathrm{Cx} 43$ sequence from residues 9-13 (KLLDK as shown in Figure 1). We synthesized this potentially interfering peptide (designated Cx43iNT1) and tested its ability to inhibit gap junction channel formed of various $\alpha$-connexins. Because Cx37, Cx45, Cx46, and Cx50 all contain multiple glutamate residues (like $\mathrm{Cx} 40$ as shown in Figure 1), we hypothesized that they might also be susceptible to block by spermine or Cx43iNT1. In the study presented below, we tested this peptide against the different $\alpha$-connexin channels and tested additional
Synthetic pentameric NT domain peptides corresponding to underlined (continuous or dotted) connexin sequences are also shown along with their peptide names. These interfering NT (iNT) peptides were protected by amino-terminal acetylation (Ac-) and carboxy-terminal amidation ( $-\mathrm{NH} 2)$ or hydroxylation $(-\mathrm{OH})$. (B) Diagram of the N2a cell pair configuration for the iNT peptide and/or spermine block experiments and the voltage step protocol used to apply the $V_{j}$ gradients across the connexin-specific gap junctions. 
transiently expressed in $\mathrm{N} 2 \mathrm{a}$ cells using the pTracer $^{\mathrm{TM}}$ vector (Chen et al., 2011).

\section{CONNEXIN INT PEPTIDE PRODUCTION}

Connexin-specific NT domain peptides were synthesized in $5 \mathrm{mg}$ quantities, high-performance liquid chromatography (HPLC) purified to $>95 \%$, and stored $\left(-20^{\circ} \mathrm{C}\right)$ as lyophilized powder until needed (Anaspec, San Jose, CA, USA). The peptides were dissolved in diethylpyrocarbonate (DEPC)-treated sterile distilled water to create a stock concentration of $10 \mathrm{mM}$, stored at $-20^{\circ} \mathrm{C}$, and $40 \mu \mathrm{l}$ aliquots were diluted with $140 \mathrm{mM} \mathrm{KCl}$ internal pipette solution (IPS) as needed for daily patch clamp experiments. The relevant connexin NT domain and peptide sequences are provided in Figure 1A. The amino and carboxyl termini of two peptides (iNT-Cx43 and iNT-Cx40b) were acetylated (amino) and amidated (carboxyl) to protect them from hydrolysis in aqueous solution. Pentameric iNT peptides for $\mathrm{Cx} 43, \mathrm{Cx} 40$, and $\mathrm{Cx} 50$ were prepared and tested in dual whole cell patch clamp experiments on homotypic Cx37, Cx40, Cx43, Cx45, Cx46, and Cx50 gap junctions expressed in N2a cells.

\section{GAP JUNCTION CONDUCTANCE $\left(\boldsymbol{g}_{j}\right)$ MEASUREMENTS}

Dual whole patch clamp experiments were performed on connexin-transfected N2a cell pairs using established procedures (Veenstra, 2001). The connexin iNT peptides were added to the patch pipette receiving the $\pm \Delta V_{\mathrm{j}}$ voltage clamp step for quantitative $g_{j}$ measurements and calculation of the fraction of unblocked junctional current $\left(I_{j}\right)$ using the previously developed spermine block $V_{\mathrm{j}}$ step protocol (Musa and Veenstra, 2003; Lin and Veenstra, 2007). Equimolar spermine concentrations were added along with the iNT peptide in some experiments to assess the ability of the peptide to antagonize the $V_{\mathrm{j}}$-dependent spermine block of $\mathrm{Cx} 40$ gap junctions. For the peptide-spermine competition experiments, iNT peptides and spermine were added at reduced concentrations $(500 \mu \mathrm{M})$ to conserve the amount of equimolar iNT peptide added to the patch pipette. The $V_{\mathrm{j}}$-dependent spermine block still achieved $70 \%$ inhibition of $\mathrm{rCx} 40 g_{j}$, sufficient to assess the action of the iNT peptides on the block by spermine.

Patch pipettes (4-5 $\mathrm{M} \Omega$ to patch break) were filled with a $\mathrm{KCl}$ IPS [in mM: KCl, 140; $\mathrm{MgCl}_{2}, 1.0 ; \mathrm{CaCl}_{2}, 3.0$; BAPTA (1,2-bis(oaminophenoxy)ethane-N,N,N' $\mathrm{N}^{\prime}$-tetraacetic acid), 5.0; HEPES (4-(2-hydroxyethyl)-1-piperazineethanesulfonic acid), 25; $\mathrm{pH}$ titrated to 7.4 using $1 \mathrm{~N} \mathrm{KOH}$ ]. The bath saline contained (in $\mathrm{mM}$ ): $\mathrm{NaCl}, 142 ; \mathrm{KCl}, 1.3 ; \mathrm{CsCl}, 4$; tetraethylammonium chloride (TEACl), 2; $\mathrm{MgSO}_{4}, 0.8 ; \mathrm{NaH}_{2} \mathrm{PO}_{4}, 0.9 ; \mathrm{CaCl}_{2}$, 1.8; dextrose, 5.5; HEPES, 10; pH 7.4 with $1 \mathrm{~N} \mathrm{NaOH}$. The osmolarity of both external and internal solutions was adjusted to $310 \mathrm{mOsm} / \mathrm{L}$. Connexin iNT and/or spermine were added to one patch pipette at the indicated concentrations. Both $\mathrm{N} 2$ a cells were held at $-40 \mathrm{mV}$ resting potential $\left(V_{\mathrm{j}}=0 \mathrm{mV}\right)$ and the cell (1) receiving the iNT peptides and/or spermine was stepped $\left(\Delta V_{1}\right)$ to varying membrane potentials to produce a $V_{\text {j gradient }}\left[V_{2}-\left(V_{1}+\Delta V_{1}\right)\right]$. Junctional conductance was calculated according to the equation:

$$
g_{\mathrm{j}}=-\Delta I_{2} /\left[\left(V_{2}-R_{\mathrm{el} 2} \cdot I_{2}\right)-\left(V_{1}-R_{\mathrm{el} 1} \cdot I_{1}\right)\right],
$$

where $\Delta I_{2}\left(=-I_{\mathrm{j}}\right)$ is the change in whole cell 2 current $\left(I_{2}\right)$ during the $\Delta V_{1}$ step, $\mathrm{R}_{\mathrm{el} 1}$ and $\mathrm{R}_{\mathrm{el} 2}$ are the respective whole cell patch electrode resistances, and $I_{1}$ and $I_{2}$ correspond to the respective whole cell currents (Veenstra, 2001). To determine the fraction of $I_{\mathrm{j}}$ block induced by the iNT-Cx43 peptide or spermine, $\Delta V_{1}$ was alternately stepped negative, positive, and negative to the common holding potential $(-40 \mathrm{mV})$ in $5 \mathrm{mV}$ increments from 5 to $50 \mathrm{mV}$ (Figure 1B). The duration of each $-/+/-\Delta V_{1}$ sequence was $90 \mathrm{~s}$ with a $500-\mathrm{ms}$ step to $-40 \mathrm{mV}$ occurring $20 \mathrm{~s}$ into each $30 \mathrm{~s}$ $-/+/-$ interval, as an internal $I_{\mathrm{j}}=0 \mathrm{pA}\left(V_{\mathrm{j}}=0 \mathrm{mV}\right)$ baseline control measurement, followed by a 30 -s rest interval. The fraction of unblocked $I_{\mathrm{j}}=\left(\Delta I_{2}\left(\right.\right.$ at positive $\left.\left.V_{\mathrm{j}}\right)\right) /\left(\Delta I_{2}\left(\right.\right.$ at negative $\left.\left.V_{\mathrm{j}}\right)\right)$. Only those experiments where the $I_{\mathrm{j}}=0$ baseline remained stable throughout the total 20 min duration of the cation block protocol were used in the final analysis.

\section{STATISTICAL ANALYSIS}

Raw data $(N \geq 3)$ from each experimental group was tested for normality by the Shapiro-Wilk test $(p$-value $<0.05)$ and then subjected to one-way ANOVA analysis $(f$-value $<0.05)$ in Origin 8.6.

\section{RESULTS \\ CX43 iNT PEPTIDE SELECTIVELY INHIBITS Cx40 GAP JUNCTION CHANNELS}

The iNT-Cx43 peptide had some structural similarity to spermine: namely terminal amino groups separated by at least $10 \mathrm{C}-\mathrm{C}$ or $\mathrm{C}-\mathrm{N}$ bonds. Therefore, we initially tested whether iNT-Cx43 peptide possessed any inhibitory activity toward $\mathrm{rCx} 40$ gap junctions. The Cx43 iNT peptide was a potent $V_{\mathrm{j}}$-dependent inhibitor of junctional conductance $\left(g_{\mathrm{j}}\right)$ in cells expressing $\mathrm{rCx} 40$; indeed, equivalent block was observed at peptide concentrations of $10 \mu \mathrm{M}$, $100 \mu \mathrm{M}$, and $1 \mathrm{mM}$ (Figures 2A,C).

Although Glu-9 contributes to the spermine block of rat $\mathrm{Cx} 40$ channels (Musa etal., 2004), this residue is replaced with an asparagine (N9) in human $\mathrm{Cx} 40$ (hCx40). Therefore, we hypothesized that hCx40 might show a different effect of iNT-Cx43 peptide. Surprisingly, we found that $100 \mu \mathrm{M}$ iNT-Cx43 peptide showed a similar inhibition of both human and rat $\mathrm{Cx} 40$ gap junctions (Figures 2B,D).

This unexpected result led us to test the ability of the $\mathrm{Cx} 43$ iNT peptide to interfere with the function of other connexins that also contain an ExxxE or ExxxD motif in their N-termini (Figure 1), Cx37, Cx46, and Cx50, or with Cx45 (which possesses only an ...EE... motif). In contrast to its effects on both rat and human isoforms of $\mathrm{Cx} 40,100 \mu \mathrm{M}$ iNT-Cx43 peptide did not affect the conductance of $\mathrm{Cx} 37, \mathrm{Cx} 45, \mathrm{Cx} 46$, or $\mathrm{Cx} 50$ gap junctions (Figure 3).

\section{CX43iNT1 PEPTIDE EFFECTS DO NOT CORRELATE WITH SPERMINE BLOCK}

Since $\mathrm{CX} 40$ (but not $\mathrm{Cx} 43$ ) exhibits $V_{\mathrm{j}}$-dependent spermine block (Musa and Veenstra, 2003; Musa et al., 2004; Lin et al., 2006; Lin and Veenstra, 2007), we tested the possible relationship of iNTCx43 block to spermine block by examining the effects of unilateral application of $2 \mathrm{mM}$ spermine on the other five connexins. Not surprisingly, hCx40 $g_{\mathrm{j}}$ was reduced in a $V_{\mathrm{j}}$-dependent manner by $2 \mathrm{mM}$ spermine (Figure 4A, black squares).

Interestingly, spermine also caused at least some inhibition of each of the other connexins. The spermine inhibition curve for 


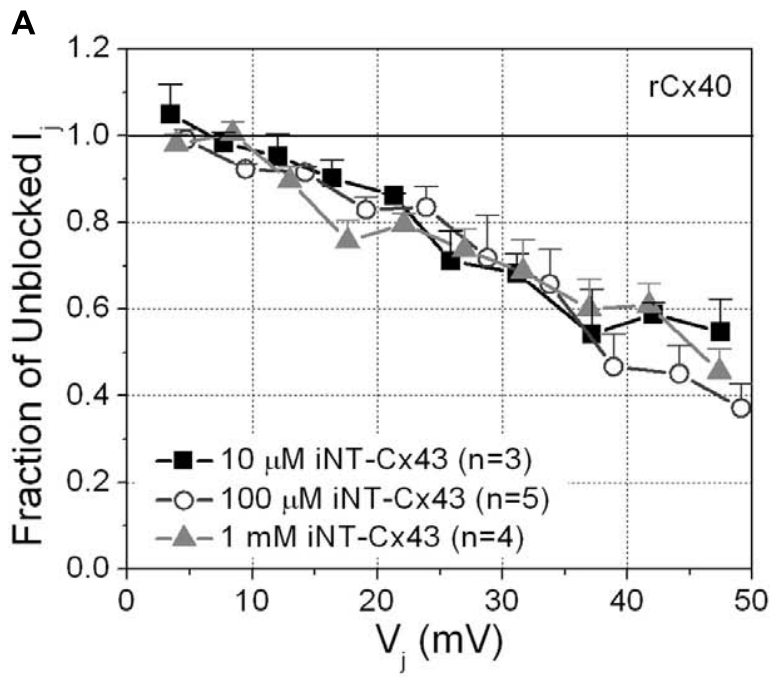

B

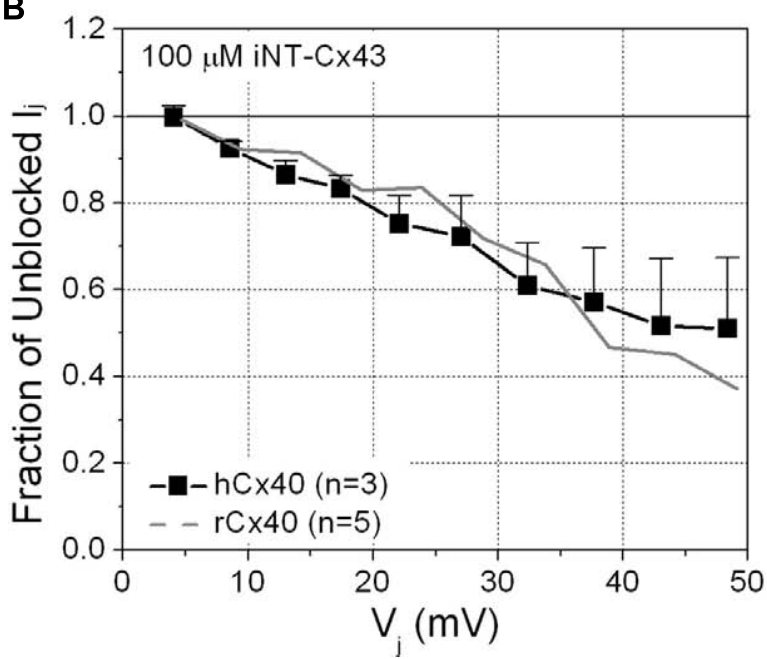

FIGURE 2 | (A) The inhibition of $\mathrm{rCx} 40$ gap junction currents $\left(/_{\mathrm{j}}\right)$ by unilateral addition of $10 \mu \mathrm{M}(\mathbf{\square}), 100 \mu \mathrm{M}(\bigcirc)$, or $1.0 \mathrm{mM}(\triangle)$ iNT-Cx43 peptide increased in a transjunctional voltage $\left(V_{j}\right)$-dependent manner. There was no statistical difference between the three curves based on comparison of the means at each $V_{j}$ value. (B) The $V_{j}$-dependent blockade of hCx40 gap junctions $(\boldsymbol{\square})$ by $100 \mu \mathrm{M}$ iNT-Cx43 peptide was not significantly different from rCx40 (continuous gray line). (C) Whole cell current traces recorded from cell 2 of a rat $\mathrm{C} \times 40$ cell pair with $100 \mu \mathrm{M}$ iNT-Cx43 peptide added to cell 1 during

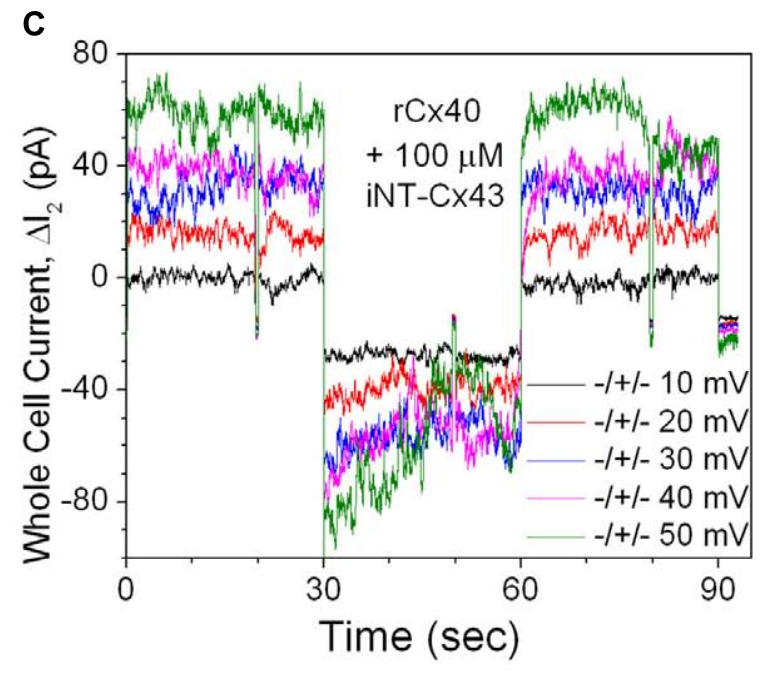

D

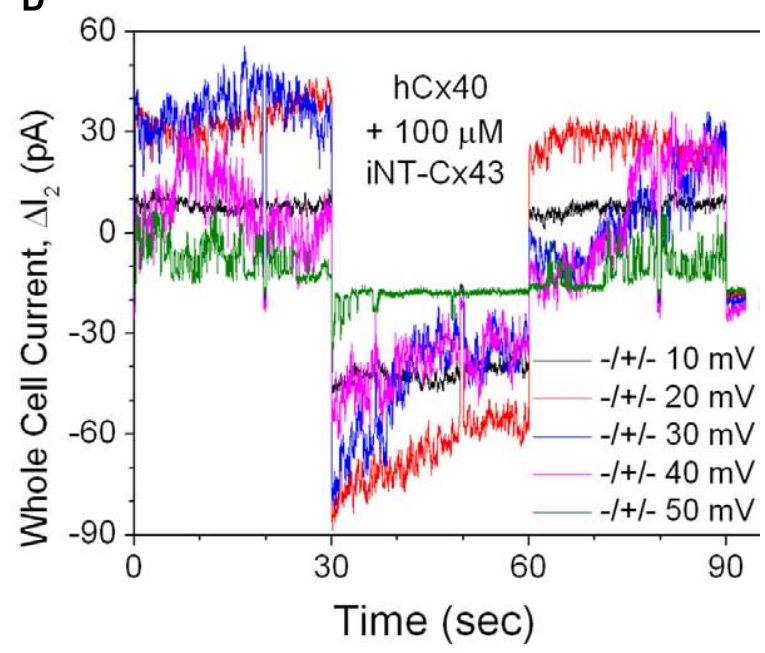

the $\Delta V_{1}$ cation block voltage clamp protocol diagrammed in Figure 1B The $\Delta I_{2}$ current $\left(=-l_{\mathrm{j}}\right)$ decrease during the $+V_{1}$ voltage steps (only $10 \mathrm{mV}$ incremental steps shown) illustrates the block induced by the iNT-Cx43 peptide. (D) Actual $\Delta / 2$ current recordings from a $\mathrm{hC} \times 40$ cell pair during an iNT-Cx43 peptide experiment illustrating a similar $V_{j}$-dependent block of hCx40 gap junction currents. Gap junction channel currents are visible at $\pm 50 \mathrm{mV}$ with reduced open probability during the positive (blocking) $V_{j}$ step.
Cx50 appeared similar to that of $\mathrm{hCx} 40$, and the maximum inhibition of $\mathrm{Cx} 50 g_{\mathrm{j}}$ was $\sim 80 \%$ (Figure $4 \mathrm{~A}$, gray circles). Cx46 $g_{\mathrm{j}}$ achieved $60 \%$ inhibition (Figure 4A, open circles). Cx37 $g_{j}$ was reduced by $>70 \%$ at low $V_{\mathrm{j}}$ values and then plateaued at $\sim 50 \%$ inhibition (Figure 4A, gray open diamonds). Spermine inhibited Cx45 $g_{j}$ by $<50 \%$ (data not shown).

Thus, the selective ability of iNT-Cx43 peptide to inhibit Cx40, but not other connexin channels, does not correlate with spermine inhibition.

\section{iNT PEPTIDE ANTAGONISM OF SPERMINE BLOCK}

Since Cx40 gap junctions were inhibited by both the Cx43iNT1 peptide and spermine, we examined whether iNT peptides based on the NT sequences of Cx40 or Cx50 (containing the ExxEE motif) could antagonize the spermine block of $\mathrm{Cx} 40$ gap junctions. Spermine block experiments were performed with or without the addition of iNT peptides.

The first Cx40 iNT peptide (iNT-Cx40a) was acetylated and amidated like the iNT-Cx43 peptide (Figure 1). iNT-Cx40a peptide was partially effective at reversing the $500 \mu \mathrm{M}$ spermine block (Figure 4B, compare gray circles to spermine alone curve indicated with solid black squares). A second $\mathrm{Cx} 40$ iNT peptide containing the EFLEE sequence, iNT-Cx40b, 9-13 peptide was synthesized where the carboxy-terminus was hydroxylated instead of amidated to prevent the neutralization of the terminal glutamic acid group (Figure 1). The iNT-Cx40b peptide totally prevented the 

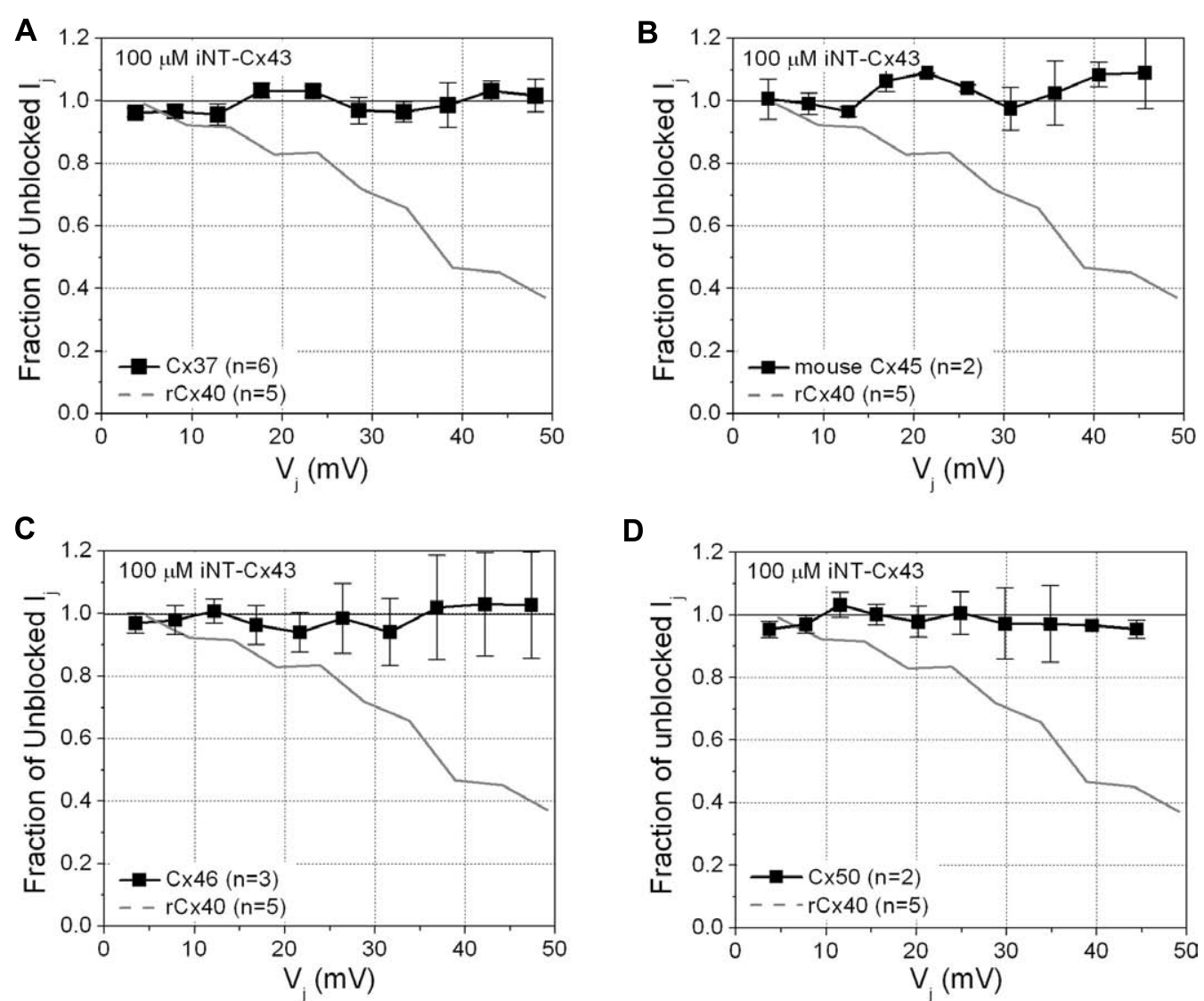

D
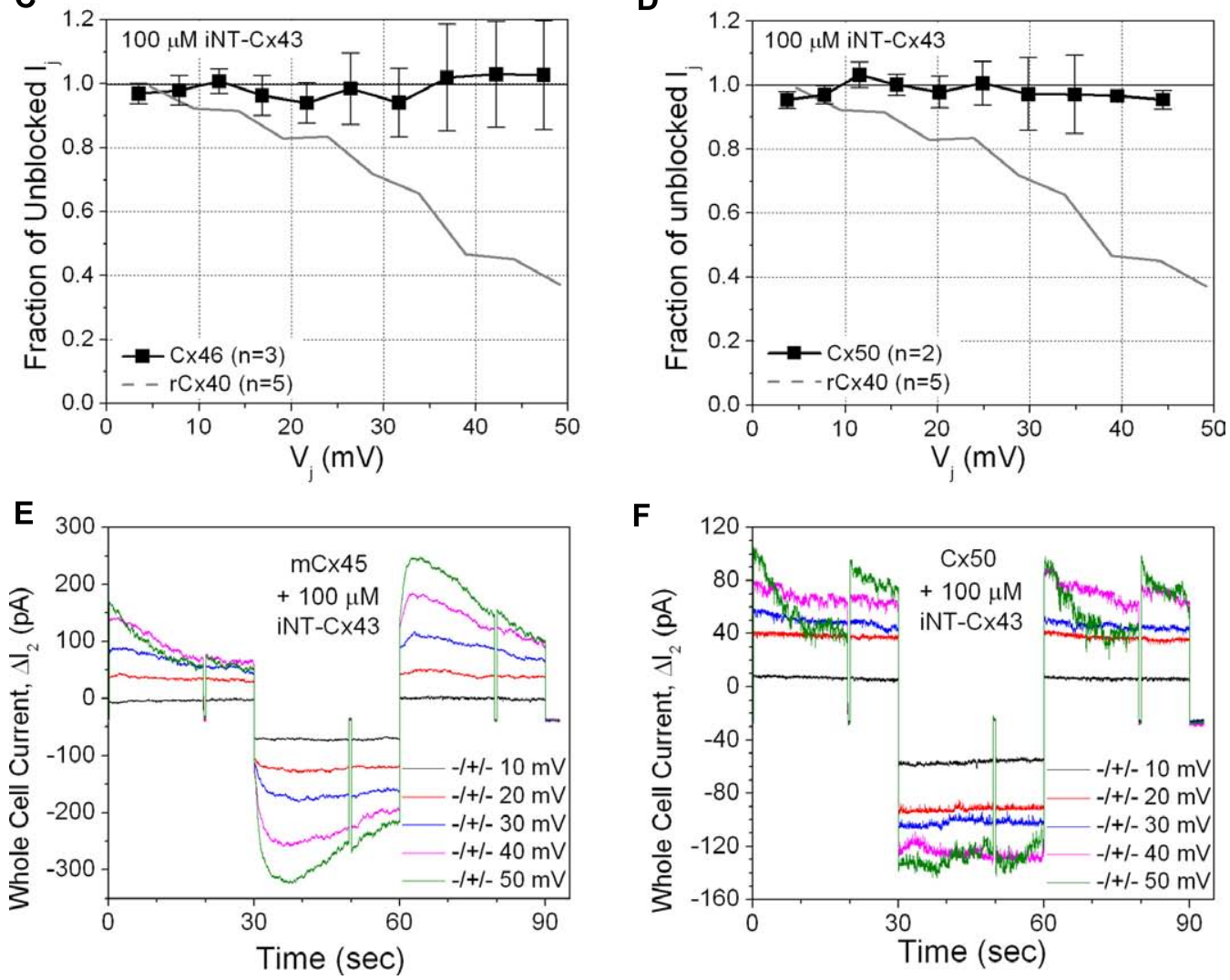

FIGURE 3 |The ability of the iNT-Cx43 peptide to inhibit Cx37 (A), Cx45 (B), Cx46 (C), and Cx50 (D) gap junctions was tested using the same $\boldsymbol{V}_{\mathrm{j}}$-dependent block protocol as in Figure 2. As a reference, the blockade of $r \mathrm{r} \times 40 I_{j}$ (continuous gray line) is illustrated in each panel. Unlike $r \mathrm{Cx} 40$, none of these four connexin gap junctions were significantly inhibited by $100 \mu \mathrm{M}$ iNT-Cx43 peptide. Actual $\Delta / 2$ current traces from $\mathrm{C} \times 45(\mathbf{E})$ and $\mathrm{C} \times 50$ (F) cell pair iNT-Cx43 peptide experiments illustrating the lack of $I_{j}$ current block

$\mathbf{F}$

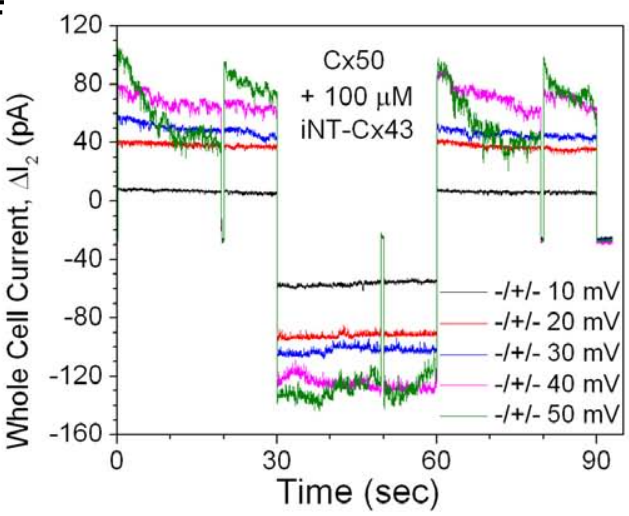

during the $+\Delta V_{1}\left(\cong V_{j}\right)$ step, in contrast to the $C \times 40$ experiments shown in Figure 2. $C \times 45$ and $C \times 50$ gap junctions are more $V_{j}$-dependent than $C \times 40$ (half inactivation $V_{j}=V_{0}$ or $V_{1 / 2} \cong \pm 30, \pm 40$, or $\pm 49 \mathrm{mV}$, respectively; Lin etal., 2006; Gonzalez et al., 2007). mCx45 gap junctions prominently display contingent hemichannel gating upon $V_{j}$ polarity reversal, proposed by Harris etal. (1981), owing to the increased $V_{j}$-dependence and lack of fast $V_{j}$-gating kinetics of these gap junctions. block of rCx40 by $500 \mu \mathrm{M}$ spermine (Figures 4B-D, dark gray circles).

These findings suggested the hypothesis that block might result from the electrostatic interaction of the ExxEE sequence. To test this hypothesis, a hydroxylated peptide corresponding to residues 12-16 of Cx50 (EEVNE), iNT-Cx50b (Figure 1), was synthesized.
iNT-Cx50b had no detectable effect on the block of rCx40 gap junctions by $500 \mu \mathrm{M}$ spermine (Figure 4E, gray circles). However, in contrast, a second hydroxylated Cx50 iNT peptide, iNT-Cx50a, corresponding to amino acids 9-13 (NILEE; Figure 1) effectively eliminated the $V_{\mathrm{j}}$-dependent spermine block of $\mathrm{rCx} 40$ gap junctions (Figure 4F). This suggested a structural requirement for 

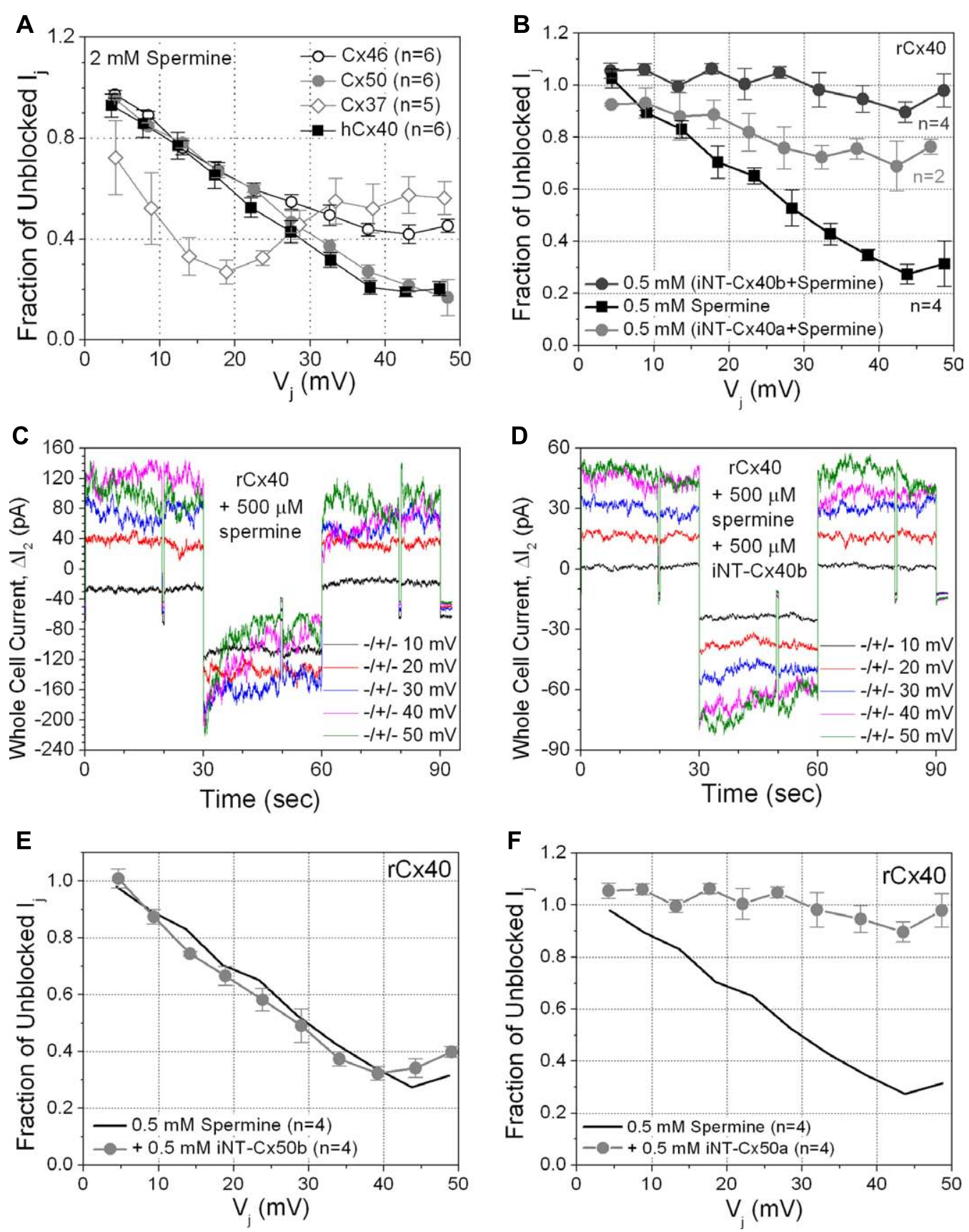

FIGURE 4 | (A) The sensitivity of four connexin-specific gap junctions was tested using the $2 \mathrm{mM}$ spermine block assay. Human Cx40 (hCx40, $\mathbf{\square}$ displayed similar $V_{j}$-dependent sensitivity to spermine as $\mathrm{rC} \times 40$ despite the N9 substitution. $\mathrm{Cx37}(\diamond), \mathrm{C} \times 46(0)$, and $\mathrm{C} \times 50(\bullet)$ gap junctions were all $\geq 60 \%$ inhibited by spermine. The maximum inhibition of $\mathrm{C} \times 37 \mathrm{~g}$ occurred at $+20 \mathrm{mV}$, half the $V_{\mathrm{j}}$ required for maximal block of any other known connexin-specific gap junction. (B) The ability of iNT-Cx40 peptides to interfere with spermine block was tested by adding $500 \mu \mathrm{M}$ spermine and iNT-Cx40a or iNT-Cx40b peptides to one patch pipette. The carboxylterminal hydroxylated $(-\mathrm{OH}, z=-4)$ form of the $\mathrm{C} x 40$ peptide ( $\mathrm{C} \times 40 \mathrm{~b})$

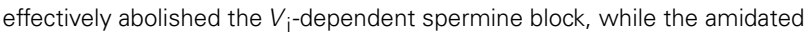
form $\left(\mathrm{C} \times 40 \mathrm{a},-\mathrm{NH}_{2}, z=-3\right.$ ) was only partially effective (ANOVA, $f$-value $<0.05$ ). (C) $\Delta / 2$ current traces from an $\mathrm{rCx} 40$ cell pair with $500 \mu \mathrm{M}$ spermine added to cell $1 . I_{j}$ decreased during the positive 30,40 , and $50 \mathrm{mV}$ $V_{j}$ pulses and returned to prepulse levels during subsequent negative $V_{j}$

pulses, This illustrates the time- and $V_{\mathrm{j}}$-dependent spermine block and unblock of $\mathrm{r} C \times 40$ gap junctions. (D) $/ 2$ current traces from an $\mathrm{rC} \times 40$ cell pair experiment with $500 \mu \mathrm{M}$ spermine and the iNT-Cx40b peptide added to cell 1. Accounting for the occurrence of $V_{j}$-dependent gating at $V_{\mathrm{j}} \geq \pm 40 \mathrm{mV}$, instantaneous and steady state $I_{2}$ increased in a stepwise (ohmic) fashion with increasing $V_{\mathrm{j}}$ amplitude, indicative of a lack of spermine block. (E) A negatively charged $(z=-4)$ iNT-Cx50b peptide failed to significantly prevent the $500 \mu \mathrm{M}$ spermine block of $\mathrm{rCx} 40$ gap junctions, suggesting that the bimolecular interactions between the $\mathrm{rC} \times 40$ NT domain, spermine, and iNT peptides are not purely based on electrostatic forces. (F) An iNT-Cx50a peptide (based on amino acids 9-13 and possessing a carboxyl-terminal valence $(z)$ of -3 ) significantly reduced the $500 \mu \mathrm{M}$ spermine block of $\mathrm{r} C \times 40$ gap junctions, suggesting a structural requirement for the interactions of iNT-Cx peptides with NT domains or spermine molecules. 
the abilities of these pentameric peptides to oppose the spermine block of $\mathrm{rCx} 40$ gap junctions.

\section{DISCUSSION}

We began this series of experiments with a relatively simple rationale: Cx40 channels which contain the sequence ExxxE in their $\mathrm{N}$-termini are inhibited by the polyamine, spermine, and might also be inhibited by a pentameric peptide derived from the NT of Cx43 which has the motif KxxxK. Indeed, we observed potent block of rCx40 channels by iNT-Cx43. The block occurred in a transjunctional voltage $\left(V_{\mathrm{j}}\right)$-dependent manner that resembled spermine block. However, the simple model of electrostatic interaction between this peptide and the connexin NT is dispelled by several other observations. The human $\mathrm{Cx} 40$ channel was also blocked by iNT-Cx43 despite the neutralization of the 9th residue in the human isoform (substitution of $\mathrm{N}$ for $\mathrm{E}$ ). Moreover, iNTCx43 peptide had no effect on $\mathrm{Cx} 37, \mathrm{Cx} 46$, or $\mathrm{Cx} 50$ gap junctions, despite the presence of a similar (ExxxE or ExxxD) motif in these connexins. There also appears to be a structural requirement for the iNT effects. While a Cx50 iNT peptide containing similarly spaced negative charges had no effect, a Cx50 iNT peptide representing amino acids 9-13 antagonized spermine block of $\mathrm{rCx} 40$.

Our data support a selective inhibitory interaction between the NT domains of Cx40 and Cx43. iNT-Cx43 only blocked Cx40 channels. This interaction appears to have a rather high affinity, since equivalent block was achieved with $10 \mu \mathrm{M}$ peptide to that produced by higher concentrations. This putative selective NT interaction parallels the observed functional heteromeric interactions among this group of connexins. The Cx43 iNT peptide exhibited no effect on $\mathrm{Cx} 37, \mathrm{Cx} 45, \mathrm{Cx} 46$, or $\mathrm{Cx} 50$ gap junctions, but blocked Cx40 channels. Similarly, functional heteromeric

\section{REFERENCES}

Arita, K., Akiyama, M., Aizawa, T., Umetsu, Y., Segawa, I., Goto, M., et al. (2006). A novel N14Y mutation in connexin26 in keratitis-ichthyosisdeafness syndrome: analyses of altered gap junctional communication and molecular structure of $\mathrm{N}$ terminus of mutated connexin26. Am. J. Pathol. 169, 416-423.

Berthoud, V. M., Montegna, E. A., Atal, N., Aithal, N. H., Brink, P. R., and Beyer, E. C. (2001). Heteromeric connexons formed by the lens connexins, connexin43 and connexin56. Eur. J. Cell Biol. 80, 11-19.

Beyer, E. C., and Berthoud, V. M. (2009). "The family of connexin genes," in Connexins: A Guide, eds A. Harris and D. Locke (New York: Humana Press), 3-26.

Brink, P. R., Cronin, K., Banach, K., Peterson, E., Westphale, E. M., Seul, K. H., et al. (1997). Evidence for heteromeric gap junction channels formed from rat connexin43 and human connexin 37. Am. J. Physiol. Cell Physiol. 273, C1386-C1396.
Bruzzone, R., Haefliger, J. A., Gimlich, R. L., and Paul, D. L. (1993). Connexin40, a component of gap junctions in vascular endothelium, is restricted in its ability to interact with other connexins. Mol. Biol. Cell 4, 7-20.

Burt, J. M., and Steele, T. D. (2003). Selective effect of PDGF on connexin43 versus connexin40 comprised gap junction channels. Cell Commun. Adhes. 10, 287-291.

Chen, Y., Zhou, Y., Lin, X., Wong, H. C., Xu, Q., Jiang, J., et al. (2011). Molecular interaction and functional regulation of connexin50 gap junctions by calmodulin. Biochem. J. 435 711-722.

Cottrell, G. T., and Burt, J. M. (2001). Heterotypic gap junction channel formation between heteromeric and homomeric $\mathrm{Cx} 40$ and $\mathrm{Cx} 43$ connexons. Am. J. Physiol. Cell Physiol. 281, C1559-C1567.

Cottrell, G. T., Wu, Y., and Burt, J. M. (2002). Cx40 and $\mathrm{Cx} 43$ expression ratio influences heteromeric/heterotypic gap junction

interactions between $\mathrm{Cx} 43$ and $\mathrm{Cx} 37, \mathrm{Cx} 45, \mathrm{Cx} 46$, and $\mathrm{Cx} 50$ have been extensively supported in the literature. We might have anticipated a reciprocal interaction of the $\mathrm{Cx} 40$ NT domain with Cx43 channels; however, we observed no effect when an iNT$\mathrm{Cx} 40$ peptide was prepared and applied to $\mathrm{Cx} 43$ gap junctions (data not shown). This negative result might have been anticipated by the lack of effect of spermine on Cx43 gap junctions (Musa and Veenstra, 2003). The lack of direct reciprocity between Cx40 and Cx43 amino termini with alternately charged sequences implies that there is a structural difference between these two NT domains beyond their oppositely charged amino acids at positions 9 and 13.

Our iNT peptide data support the conclusion that $\mathrm{Cx} 40$ and Cx43 can form heteromeric channels, but most (if not all) of them will be non-functional (closed) due to the interactions of their amino termini. It is likely that a single $\mathrm{Cx} 43$ subunit is sufficient to nullify the function of a heteromeric $\mathrm{Cx} 40-\mathrm{Cx} 43$ hemichannel (connexon), based on the stoichiometric study of N2D and N2E mutant $\mathrm{Cx} 32^{*} \mathrm{Cx} 43 \mathrm{E} 1$ hemichannels showing that a single NT domain is sufficient to induce $V_{\mathrm{j}}$-dependent closure of a connexin hemichannel (Oh et al., 2000).

Finally, the connexin-specific effects of these iNT peptides also suggest the possibility of designing drugs that serve as gap junction agonists or antagonists by altering modulatory $V_{j}$ or chemical gating interactions involving unique connexin domains. For instance, the Cx43 iNT peptide may antagonize the aberrant function of mutant $\mathrm{Cx} 40$ hemi- or gap junction channels associated with atrial fibrillation (Gollob et al., 2006; Yang et al., 2010).

\section{ACKNOWLEDGMENTS}

The project was supported by NIH grants HL-042220 to Richard D. Veenstra and HL-059199 to Eric C. Beyer and Richard D. Veenstra.

channel properties. Am. J. Physiol Cell Physiol. 282, C1469-C1482.

Dong, L., Liu, X., Li, H., Vertel, B. M., and Ebihara, L. (2006). Role of the N-terminus in permeability of chicken connexin 45.6 gap junctional channels. J. Physiol. 576, 787-799.

Elenes, S., Martinez, A. D., Delmar, M., Beyer, E. C., and Moreno, A. P. (2001). Heterotypic docking of $\mathrm{cx} 43$ and $\mathrm{cx} 45$ connexons blocks fast voltage gating of cx43. Biophys. J. 81, 1406-1418.

Elfgang, C., Eckert, R., LichtenbergFrate, H., Butterweck, A., Traub, O., Klein, R. A., et al. (1995). Specific permeability and selective formation of gap junction channels in connexintransfected HeLa cells. J. Cell Biol. $129,805-817$.

Gemel, J., Lin, X., Veenstra, R. D. and Beyer, E. C. (2006). N-terminal residues in $\mathrm{Cx} 43$ and $\mathrm{Cx} 40$ determine physiological properties of gap junction channels, but do not influence heteromeric assembly with each other or with Cx26. J. Cell Sci. 119, 2258-2268.

Gemel, J., Valiunas, V., Brink, P. R., and Beyer, E. C. (2004). Connexin 43 and connexin 26 form gap junctions, but not heteromeric channels in coexpressing cells. J. Cell Sci. 117, 2469-2480.

Gollob, D. A., Jones, D. L., Krahn, A. D., Danis, L., Gong, X.-Q., Shao, Q., et al. (2006). Somatic mutations in the connexin 40 gene (GJA5). N. Engl. J. Med. 354, 2677-2688.

Gonzalez, D., Gomez-Hernandez, J. M., and Barrio, L. C. (2007). Molecular basis of voltage dependence of connexin channels: an integrative appraisal. Prog. Biophys. Mol. Biol. 94, 66-106.

Harris, A. L., Spray, D. C., and Bennett, M. V. (1981). Kinetic properties of a voltage-dependent junctional conductance. J. Gen. Physiol. 77, 95-117.

Haubrich, S., Schwartz, H.-J., Bukauskas, F., Lichtenberg-Frate, H., Traub, O., Weingart, R., et al. (1996). Incompatibility of connexin 40 and 43 hemichannels in gap junctions between mammalian cells is determined by intracellular domains. Mol. Biol. Cell 7, 1995-2006.

He, D. S., Jiang, J. X., Taffet, S. M., and Burt, J. M. (1999). Formation 
of heteromeric gap junction channels by connexins 40 and 43 in vascular smooth muscle cells. Proc. Natl. Acad. Sci. U.S.A. 96, 6495-6500.

Heyman, N. S., Kurjiaka, D. T., Ek Vitorin, J. F., and Burt, J. M. (2009). Regulation of gap junctional charge selectivity in cells coexpressing connexin 40 and connexin 43. Am. J. Physiol. Heart Circ. Physiol. 297, H450-H459.

Igarashi, K., and Kashiwagi, K. (2000). Polyamines: mysterious modulators of cellular functions. Biochem. Biophys. Res. Commun. 271, 559-564.

Kalmatsky, B. D., Bhagan, S., Tang, Q., Bargiello, T. A., and Dowd, T. L. (2009). Structural studies of the Nterminus of connexin 32 using $1 \mathrm{H}$ NMR spectroscopy. Arch. Biochem. Biophys. 490, 9-16.

Kumar, N. M., and Gilula, N. B. (1992). Molecular biology and genetics of gap junction channels. Semin. Cell Biol. 3, 3-16.

Kyle, J. W., Berthoud, V. M., Kurutz, J., Minogue, P. J., Greenspan, M., Hanck, D. A., et al. (2009). The N terminus of connexin 37 contains an $\alpha$-helix that is required for channel function. J. Biol. Chem. 284, 20418-20427.

Lagree, V., Brunschwig, K., Lopez, P., Gilula, N. B., Richard, G., and Falk, M. M. (2003). Specific aminoacid residues in the $\mathrm{N}$-terminus and TM3 implicated in channel function and oligomerization compatibility of connexin43. J. Cell Sci. 116, 31893201.

Lin, X., Fenn, E., and Veenstra, R. D. (2006). An amino-terminal lysine residue of rat connexin 40 that is required for spermine block. J. Physiol. 570, 251-269.

Lin, X., and Veenstra, R. D. (2007) Effect of transjunctional $\mathrm{KCl}$ gradients on the spermine inhibition of connexin40 gap junctions. Biophys. J. 93, 483-495.

Lin, X., Xu, Q., and Veenstra, R. D. (2011). "Formation of heterotypic gap junctions by connexins -40 and
-43," in International Gap Junction Conference Proceedings, abstract \# 1.7.

Maeda, S., Nakagawa, S., Suga, M. Yamashita, E., Oshima, A., Fujiyoshi, Y., etal. (2009). Structure of the connexin 26 gap junction channel at $3.5 \AA$ resolution. Nature 458, 597-602.

Martinez, A. D., Hayrapetyan, V., Moreno, A. P., and Beyer, E. C. (2002). Connexin43 and connexin45 form heteromeric gap junction channels in which individual components determine permeability and regulation. Circ. Res. 90, 1100-1107.

Martinez, A. D., Maripillan, J., Acuna, R., Minogue, P. J., Berthoud, V. M. and Beyer, E. C. (2011). Different domains are critical for oligomerization compatibility of different connexins. Biochem. J. 436, 35-43.

Maza, J., Das, S. J., and Koval, M. (2005). Defining a minimal motif required to prevent connexin oligomerization in the endoplasmic reticulum. J. Biol. Chem. 280, 21115-21121.

Musa, H., Fenn, E., Crye, M., Gemel, J., Beyer, E. C., and Veenstra, R. D. (2004). Amino terminal glutamate residues confer spermine sensitivity and affect voltage gating and channel conductance of rat connexin40 gap junctions. J. Physiol. 557, 863-878.

Musa, H., Gough, J. D., Lees, W. J. and Veenstra, R. D. (2001). Ionic blockade of the rat connexin40 gap junction channel by large tetraalkylammonium ions. Biophys. J. 81, 3253-3274.

Musa, H., and Veenstra, R. D. (2003). Voltage-dependent blockade of connexin40 gap junctions by spermine. Biophys. J. 84, 205-219.

Oh, S., Abrams, C. K., Verselis, V. K., and Bargiello, T. A. (2000). Stoichiometry of transjunctional voltage-gating polarity reversal by a negative charge substitution in the amino terminus of a connexin32 chimera. J. Gen. Physiol. 116, 13-32.

Oh, S., Rivkin, S., Tang, Q., Verselis, V. K., and Bargiello, T. A. (2004). Determinants of gating polarity of a connexin 32 hemichannel. Biophys. J. 87, 912-928.

Pegg, A. E. (2009). Mammalian polyamine metabolism and function. IUBMB Life 61, 880-894.

Purnick, P. E., Benjamin, D. C., Verselis, V. K., Bargiello, T. A., and Dowd, T. L. (2000). Structure of the amino terminus of a gap junction protein. Arch. Biochem. Biophys. 381, 181-190.

Rackauskas, M., Kreuzberg, M. M. Pranevicius, M., Willecke, K., Verselis, V. K., and Bukauskas, F. F. (2006). Gating properties of heterotypic gap junction channels formed of connexins 40, 43 and 45. Biophys. J. 92, 1952-1965.

Tong, J. J., and Ebihara, L. (2006). Structural determinants for the differences in voltage gating of chicken $\mathrm{Cx} 56$ and Cx45.6 gap-junctional hemichannels. Biophys. J. 91, 2142-2154.

Valiunas, V., Gemel, J., Brink, P. R. and Beyer, E. C. (2001). Gap junction channels formed by coexpressed connexin40 and connexin43. Am. J. Physiol. Heart Circ. Physiol. 281, H1675-H1689.

Valiunas, V., Weingart, R., and Brink, P R. (2000). Formation of heterotypic gap junction channels by connexins 40 and 43. Circ. Res. 86, E42-E49.

Veenstra, R. D. (2001). Voltage clamp limitations of dual whole-cell gap junction current and voltage recordings. I. Conductance measurements. Biophys. J. 80, 2231-2247.

Veenstra, R. D. (2003). Towards gap junction channel structure. Recent Res. Dev. Biophys. 2, 65-94.

Veenstra, R. D., and Lin, X. (2006). More on the pore of gap junction channels. Recent Res. Dev. Biophys. 5, 1-35.

Veenstra, R. D., Wang, H. Z., Beyer, E. C., and Brink, P. R. (1994). Selective dye and ionic permeability of gap junction channels formed by connexin 45 . Circ. Res. 75, 483-490.

White, T. W., Bruzzone, R., Wolfram, S., Paul, D. L., and Goodenough, D. A. (1994). Selective interactions among the multiple connexin proteins expressed in the vertegrate lens: the second extracellular domain is a determinant of compatibility between connexins. J. Cell Biol. 125, 879-892.

White, T. W., Paul, D. L., Goodenough, D. A., and Bruzzone, R. (1995). Functional analysis of selective interactions among rodent connexins. Mol. Biol. Cell 6, 459-470.

Xu, Q., Kopp, R. F., Chen, Y., Yang, J. J., Roe, M. W., and Veenstra, R. D. (2012). Gating of connexin 43 gap junctions by a cytoplasmic loop calmodulin binding domain. Am. J. Physiol. Cell Physiol. 302, C1548C1556.

Yang, Y.-Q., Liu, X., Zhang, X.-L., Wang, X.-H., Tan, H.-W., Shi, H.F, et al. (2010). Novel connexin 40 missense mutations in patients with familial atrial fibrillation. Europace 12, 1421-1427.

Conflict of Interest Statement: The authors declare that the research was conducted in the absence of any commercial or financial relationships that could be construed as a potential conflict of interest.

Received: 19 February 2013; paper pending published: 04 March 2013; accepted: 29 April 2013; published online: 21 May 2013.

Citation: Beyer EC, Lin X and Veenstra $R D$ (2013) Interfering amino-terminal peptides and functional implications for heteromeric gap junction formation. Front. Pharmacol. 4:67. doi: 10.3389/ fphar.2013.00067

This article was submitted to Frontiers in Pharmacology of Ion Channels and Channelopathies, a specialty of Frontiers in Pharmacology.

Copyright (C) 2013 Beyer, Lin and Veenstra. This is an open-access article distributed under the terms of the Creative Commons Attribution License, which permits use, distribution and reproduction in other forums, provided the original authors and source are credited and subject to any copyright notices concerning any third-party graphics etc. 